\title{
PELAKSANAAN TANGGUNG JAWAB PERUSAHAAN DAERAH AIR MINUM (PDAM) DALAM PENYALURAN AIR BERSIH KEPADA PELANGGAN DI KOTA MAKASSAR
}

\section{ABSTRAK}

Asrul Aswar, Pelaksanaan Tanggung Jawab Perusahaan Daerah Air Minum (PDAM) Dalam Penyaluran Air Bersih Kepada Pelanggan Di Kota Makassar dibimbing oleh H. Sufirman Rahman dan H. Abdul Qahar.

Penelitian ini bertujuan Untuk mengetahui pelaksanaan tanggung jawab Perusahaan Daerah Air Minum (PDAM) dalam penyaluran air bersih kepada pelanggan di Kota Makassar. Selain itu, untuk mengetahui upaya hukum apa yang dilakukan oleh pihak pelanggan dalam hal terjadi wanprestasi oleh pihak Perusahaan Daerah Air Minum (PDAM). Metode penelitian ini dilaksanakan pada Kantor Perusahaan Daerah Air Minum (PDAM) Kota Makassar dengan menggunakan metode pendekatan yuridis empiris. Pendekatan yuridis empiris digunakan untuk memberikan gambaran secara kualitatif tentang tanggung jawab PDAM dan penyelesaian permasalahan dalam pelaksanaan perjanjian. Pendekatan empiris dimaksudkan ialah sebagai usaha mendekati masalah yang diteliti dengan sifat hukum yang nyata atau sesuai dengan kenyataan dalam masyarakat. Pengumpulan data dilakukan dengan cara penelitian lapangan melalui wawancara, dokumentasi dan pengamatan serta penelitian kepustakaan dilakukan untuk mendapatkan data sekunder yang berasal dari buku-buku, artikel, dan sumber-sumber lain yang relevan dengan masalah diatas. Data yang telah dikumpulkan diklasifikasikan dan dianalisis secara kualitatif selanjutnya diuraikan secara deskriptif dengan metode induktif dan deduktif.

Hasil penelitian ini menunjukkan bahwa pelaksanaan tanggung jawab pihak pengelolah air minum punya batas tertentu, adapun upaya dalam penyelesaian sengketa yang timbul antara para pelanggan dengan pihak Perusahaan Daerah Air Minum (PDAM) Kota Makassar, yaitu diupayakan terlebih dahulu diselesaikan secara musyawarah untuk mufakat, dan kalau upaya itu tidak terwujud maka melalui jalur hukum atau diteruskan ke pengadilan.

Sebagai saran dalam pelayanan penyaluran air minum oleh Perusahaan Daerah Air Minum (PDAM) Kota Makassar kepada setiap pelanggan, masih perlu ditingkatkan, termasuk harus kontinyu dalam menyalurkan air, penyaluran air tidak boleh selalu macet (debit air kecil), dan air yang disalurkan harus bersih dari segala kotoran dan tidak keruh. Serta, untuk menghindari terjadinya permasalahan antara Perusahaan Daerah Air Minum (PDAM) Kota Makassar dengan pihak pelanggan air minum, maka masing-masing pihak memahami dengan baik hak-hak dan kewajibannya dalam kaitannya dengan penyaluran air bersih tersebut serta Pihak PDAM memberikan masing-masing pegangan kepada pelanggan salinan perjanjian yang telah disepakati kedua belah pihak. 


\begin{abstract}
Asrul Aswar, Implementation Responsibility Regional Water Company (PDAM) In Water Distribution To Customers In Makassar guided by H. Sufirman Rahman and H. Abdul Qahar.

This study aims to investigate the implementation of the responsibility of the Regional Water Company (PDAM) in water distribution to customers in the city of Makassar. In addition, to determine what legal action taken by the customer in the event of default by the Regional Water Company (PDAM). The research method was conducted in the Office of the Regional Water Company (PDAM) Makassar City using empirical juridical approach. Juridical empirical approach is used to provide a qualitative description of the responsibilities of taps and settlement issues in the implementation of the agreement. Empirical approach is intended as an attempt to approach the problem under study with real legal nature or according to the reality in society. Data collection was performed by means of field research through interviews, observation and documentation and library research conducted to obtain secondary data derived from books, articles, and other sources that are relevant to the above problems. The data have been collected and analyzed qualitatively classified further described descriptively with inductive and deductive methods.
\end{abstract}

The results of this study indicate that the implementation of the responsibilities of the parties distributor drinking water has a certain extent, while the efforts in the settlement of disputes arising between the customer with the Regional Water Company (PDAM) of Makassar, which sought first settled by discussion and consensus, and if The effort did not materialize so through legal channels or forwarded to the court.

As a suggestion in drinking water delivery service by the Regional Water Company (PDAM) Makassar to each customer, it still needs to be improved, including the need to continuously deliver water, water delivery should not always jammed (small water flow), and water applied must be clean of all the dirt and not cloudy. As well, to avoid problems between the Regional Water Company (PDAM) of Makassar with the customer's drinking water, then each party understands well the rights and obligations in relation to the distribution of clean water and taps Party gives each handle to the customer a copy of the agreement that has been agreed by both parties. 


\section{PENDAHULUAN}

\section{A. Latar Belakang Masalah}

Air merupakan salah satu kebutuhan vital bagi makhluk hidup untuk tetap bertahan hidup disamping udara, tanah dan cahaya. Tidak semua air bias langsung dikonsumsi dan/atau digunakan oleh manusia dalam memenuhi kebutuhannya sehari-hari. Air yang dibutuhkan manusia adalah air yang memenuhi persyaratan sebagai air bersih. Seringkali terdapat persepsi di masyarakat yang menyamakan antara air bersih dengan air minum. Namun hal ini tidak sepenuhnya benar, menurut Peraturan Menteri Kesehatan Republik Indonesia Nomor 907/MENKES/SKIVII/2002 Tentang Syarat-syarat dan Pengawasan Kualitas Air Minum disebutkan bahwa: air bersih adalah air yang dapat digunakan untuk keperluan sehari-hari yang kualitasnya memenuhi syarat kesehatan dan dapat diminum apabila telah masak, sedang air minum adalah air yang melalui proses pengolahan atau tanpa melalui proses pengolahan yang memenuhi syarat kesehatan dan dapat langsung diminum.

Semakin pesatnya pertumbuhan penduduk di Kota Makassar memicu juga tingginya kebutuhan air bersih yang memadai bagi masyarakat. Air bersih sangat dibutuhkan oleh masyarakat mulai dari masyarakat ekonomi rendah sampai masyarakat berekonomi tinggi. Untuk menunjang kebutuhan air bersih itu, masyarakat ada yang memperoleh dari mata air sumur namun sebagian besar masyarakat di Kota Makassar ini menggantungkan keperluan air bersih untuk keperluan sehari-harinya dari Perusahaan Daerah Air Minum (PDAM) Kota Makassar. Dengan kata lain keberadaan Perusahaan Daerah Air Minum (PDAM) di tengahtengah masyarakat sangat penting artinya seperti PDAM di Kota Makassar untuk 
menyalurkan air bersih yang bebas dari segala penyakit kepada setiap para pelanggan air minum di daerah ini.

Fungsi yang diemban pihak PDAM ini, adalah untuk memberikan kemudahan bagi penduduk kota untuk memperoleh air bersih, dimana air bersih tersebut merupakan kebutuhan yang paling utama dan selalu digunakan setiap hari, baik digunakan sebagai air minum, kebutuhan untuk memasak serta mencuci dan keperluan lainnya.

Dapat dibayangkan, sekiranya air tersebut tersedia dalam kapasitas yang tidak cukup dan tidak layak untuk digunakan oleh masyarakat, tentunya warga masyarakat di Kota Makassar akan mengalami masalah paling mendesak, sebab air termasuk kebutuhan utama disamping kebutuhan lainnya.

Pengaturan serta pendistribusian air minum pada setiap rumah tangga atau para pelanggan, merupakan pekerjaan yang sulit serta harus tepat dan mencukupi, jika pihak penyedia air minum dalam hal ini PDAM Kota Makassar tidak dapat menjalankan fuggsinya, maka jelas akan menimbulkan masalah hukum terhadap para pelanggan atau konsumen.

Sebelum pihak Perusahaan Daerah Air Minum yang menyalurkan air minum kepada pelanggan, terlebih dahulu terjadi hubungan hukum yang mengikat para pihak. Hubungan mana diawali dengan suatu perjanjian (Surat Perjanjian Jual Beli Air Minum), isi dari perjanjian yang dituangkan dalam Surat Perjanjian Jual Beli Air Minum telah ditetapkan secara sepihak oleh PDAM sehingga perjanjian tersebut merupakan perjanjian standar atau perjanjian baku.

Seperti yang tercantum dalam Pasal 18 Undang-undang Perlindungan Konsumen, perjanjian standar/baku bisa diartikan sebagai perjanjian yang mengatur hak dan kewajiban masing-masing pihak telah ditentukan dalam surat perjanjian itu sehingga calon konsumen (pelanggan) hanya tinggal menandatangani formulir tersebut yang sebenarnya lebih banyak 
mengatur mengenai kewajiban-kewajiban pelanggan. Sejak dari awal saja sebenarnya konsumen telah dirugikan oleh PDAM. Tapi mengingat ketergantungan warga akan air dari PDAM, maka ketidakseimbangan posisi pelaku usaha (PDAM) dan konsumen pelanggan air minum akan sering terjadi. Ketidakseimbangan itu terjadi karena konsumen tidak dapat secara bebas ikut menentukan isi perjanjian itu. Hal ini dapat menimbulkan terjadinya ketidakadilan bagi konsumen, mengingat yang menentukan syarat perjanjian hanya salah satu pihak. Pembuatan suatu perjanjian ini sebagai formalitas untuk mengantisipasi apabila kelak dikemudian hari timbul permasalahan dalam jual-beli. Peraturan yang terkait mengenai hal ini tidak ada satupun yang mengatur bila terjadi pelanggaran kewajiban oleh PDAM, sebaliknya yang ada adalah peraturan jika konsumen melanggar kewajibannya.

Di samping itu pada Pasal 4a Undang-undang Nomor 8 Tahun 1999 tentang Perlindungan Konsumen yang menyatakan bahwa "hak atas kenyamanan, keamanan, dan keselamatan dalam mengkonsumsi barang dan/atau jasa", berdasarkan pada pasal tersebut menegaskan bahwa pelanggan/konsumen memepunyai hak dari pelaku usaha untuk melaksanakan kewajibannya dalam hal kenyamanan, keamanan, dan keselamatan dalam mengkonsumsi barang dan/atau jasa yang diperjanjikan (diperjualbelikan).

Perjanjian jual beli air minum menimbulkan hak dan kewajiban yang harus diperhatikan dan dilaksanakan oleh kedua belah pihak baik PDAM sebagai penyedia dan penyalur air minum maupun konsumen sebagai pelanggan, yang mempunyai hak untuk mendapat penyaluran air minum yang baik sesuai dengan perjanjian yang disepakati,

Berdasarkan hal tersebut tampak secara jelaslah bahwa setelah kewajiban para pelanggan membayar uang pendistribusian/rekening air, di pihak lain Perusahaan Daerah Air Minum berkewajiban untuk menyalurkan air minum dalam kapasitas yang cukup, bersih dan layak untuk digunakan bagi para pelanggannya. 
Di samping itu tanggung jawab Perusahaan Daerah Air Minum untuk menyalurkan air minum yang bersih kepada setiap pelanggannya dibutuhkan kecermatan dan ketepatan, sebab selalu dibutuhkan tiap hari, jika tidak, maka akan menimbulkan kerugian bagi para pelanggan yang telah membayar rekening air untuk memenuhi kewajibannya, oleh karena itu timbul haknya untuk menerima pendistribusian air sesuai dengan kapasitas debit air yang tersedia pada perusahaan tersebut.

Hal-hal yang telah diatur dalam Undang-undang Republik Indonesia Nomor 8 Tahun 1999 tentang Perlindungan Konsumen sangat sering diacuhkan oleh produsen dan ironisnya konsumen sendiripun seakan tidak mengerti dan tidak mau belajar mengenai hal itu. Demikian juga dengan permasalahan air bersih, bahkan untuk daerah Kota Makassar hal ini masih terjadi.

Di YLKI, Sekertaris Yayasan Lembaga Konsumen Sulawesi Selatan Yudi Raharjo mengatakan selama ini konsumen mengeluhkan distribusi air yang tidak merata. "Ada daerah yang baru mengalir pada saat subuh". (Tempo.Co, Selasa, 30 April 2013 | 21:11).

\section{B. Rumusan Masalah}

Berdasarkan latar belakang masalah tersebut penulis ingin mengetahui Masalahmasalah inilah yang akan dibahas lebih lanjut dalam karya ilmiah ini, untuk lebih jelas dalam hal pemahamannya maka penulis memberikan garis besarnya yaitu :

1. Sejauhmanakah pelaksanaan tanggung jawab PDAM dalam penyaluran air bersih kepada pelanggan di Kota Makassar? 


\section{Tujuan Penelitian}

Sebagaimana diketahui bahwa setiap penulisan atau penyusunan suatu laporan pastilah mempunyai tujuan serta kegunaan tersendiri. Demikian pula dalam penulisan karya ilmiah ini mempunyai tujuan dan kegunaan untuk memberikan motifasi atau memberikan masukan-masukan kepada unsur-unsur yang terkait. Adapun tujuan dari penulisan proposal tesis ini adalah sebagai berikut :

1. Untuk mengetahui pelaksanaan tanggung jawab Perusahaan Daerah Air Minum (PDAM) dalam penyaluran air bersih kepada pelanggan di Kota Makassar.

2. Untuk mengetahui upaya hukum apa yang dilakukan oleh pihak pelanggan dalam hal terjadi wanprestasi oleh pihak Perusahaan Daerah Air Minum (PDAM).

\section{Manfaat Penelitian}

1. Manfaat Teoritis

- Untuk mengembangkan ilmu pengetahuan melalui kegiatan penelitian.

- Untuk membandingkan kebenaran pengetahuan yang diperoleh di lapangan sehingga mengetahui perbedaan dan persamaan yang jelas antara teori yang ada dengan praktek pelaksanaannya yang selanjutnya dapat dikembangkan guna memperoleh pengetahuan yang diharapkan dapat memberikan bahan masukan bagi usaha perlindungan konsumen pemakai jasa PDAM Makassar.

2. Manfaat Praktis

- Melalui penelitian ini diharapkan dapat memberikan sumbangan pemikiran bagi berbagai pihak yang terlibat baik langsung maupun tidak langsung dalam usaha pelaksanaan perlindungan hukukm dan penyelesaian hak-hak konsumen PDAM khususnya di Kota Makassar. 
- Melalui penelitian ini diharapkan dapat memberikan masukan bagi pihak PDAM Makassar sebagai pelaku usaha dalam pelaksanaan upaya perlindungan konsumen dalam rangka pelayanan jasa air bersih di Kota Makassar. 


\section{METODE PENELITIAN}

\section{A. Tipe Penelitian}

Berdasarkan perumusan masalah dan tujuan penelitian, maka metode pendekatan yang digunakan adalah pendekatan yuridis empiris. Pendekatan yuridis empiris digunakan untuk memberikan gambaran secara kualitatif tentang kewajiban pelanggan PDAM dan penyelesaian permasalahan dalam pelaksanaan perjanjian.

Pendekatan yuridis diartikan sebagai pendekatan terhadap aturan-aturan hukum yang berhubungan dengan perbuatan hukum mengenai pelaksanaan perjanjian Penyaluran Air Bersih. Pendekatan empiris dimaksudkan ialah sebagai usaha mendekati masalah yang diteliti dengan sifat hukum yang nyata atau sesuai dengan kenyataan dalam masyarakat.

\section{B. Lokasi Penelitian}

Penelitian ini berlokasi di Kantor PDAM Kota Makassar, dengan pertimbangan bahwa PDAM Kota Makassar juga menyalurkan air minum kepada masyarakat, yang secara otomatis akan mengalami problematika hukum.

\section{A. Kesimpulan}

Pelaksanaan tanggung jawab pihak pengelolah air minum punya batas tertentu, artinya selain tanggung jawab penuh terhadap panyaluran air minum yang bersih setiap hari (secara kontinyu) kepada setiap pelanggan, juga bertanggung jawab terhadap hal-hal lainnya diluar dari pada tugasnya yang 
utamanya itu. Pelaksanaan hak dan kewajiban para pihak dalam hal penyaluran air minum yang dilakukan oleh Pihak Perusahaan Daerah Air Minum (PDAM) Kota Makassar, yaitu bahwa setiap pelanggan air minum akan diberikan pelayanan yang maksimal.

\section{B. Saran}

Pelayanan penyaluran atau pendistribusian air minum oleh Perusahaan Daerah Air Minum (PDAM) Kota Makassar kepada setiap pelanggan, masih perlu ditingkatkan, termasuk harus kontinyu dalam menyalurkan air, penyaluran air tidak boleh selalu macet (debit air kecil), dan air yang disalurkan harus bersih dari segala kotoran dan tidak keruh. 


\section{DAFTAR PUSTAKA}

\section{BUKU}

Abdul Kadir Muhammad, 1992, Hukum Perikatan, PT. Citra Aditya Bakti, Bandung.

Ahmadi Miru dan Sutarman Yodo, 2004. Hukum Perlindungan Konsumen, Raja Grafindo Persada, Jakarta

, 2011, Prinsip-Prinsip Perlindungan Konsumen Indonesia, Raja Grafindo Persada, Jakarta.

Aridwan Halim, 2005. Pengantar IImu Hukum Dalam Tanya Jawab, Ghalia Indonesia, Bogor.

Az. Nasution. 2002, Hukum Perlindungan Konsumen, Suatu Pengantar, Cet. 2. Diadit Media, Jakarta.

Gunawan Widjaja dan Ahmad Yani. 2000, Hukum Tentang Perlindungan Konsumen, PT. Gramedia Pusaka Utama, Jakarta.

Hans Kelsen, 2006, sebagaimana diterjemahkan oleh Raisul Mutaqien, Teori Hukum Murni, Nuansa \& Nusamedia, Bandung. , 2007, sebagaimana diterjemakan oleh Somardi, General Theory Of law and State, Teori UmumHukum dan Negara, Dasar-dasar IImu Hukum Normatif Sebagai IImu Hukum Deskriptif- Empirik, BEE Media Indonesia, Jakarta.

Harahap, M. Yahya, 1983, Hukum Perjanjian, Ghalia Indonesia, Jakarta.

, 1985, Segi-Segi Hukum Perjanjian, Ghalia Indonesia, Jakarta.

, 1987, Intisari Hukum Perjanjian, Alumni, Bandung.

, 1993 "Dua Sisi Putusan Hakim Tidak Adil bagi yang Kalah dan Adil bagi yang Menang,"Varia Peradilan, Tahun VIII No. 95 (Edisi : Agustus)

Indah Sukmaningsih, 1997. Dimensi Pelayanan Publik dalam Masalah Perlindungan Konsumen, Lokakarya Hukum Perlindungan Konsumen Bagi Dosen dan Praktisi Hukum, Jakarta. 